2012

\title{
The Use of Voluntary Disclosure Initiatives in the Battle Against Offshore Tax Evasion
}

Leandra Lederman

Follow this and additional works at: https://digitalcommons.law.villanova.edu/vlr

Part of the Banking and Finance Law Commons, Taxation-Transnational Commons, and the Tax Law Commons

\section{Recommended Citation}

Leandra Lederman, The Use of Voluntary Disclosure Initiatives in the Battle Against Offshore Tax Evasion, 57 Vill. L. Rev. 499 (2012).

Available at: https://digitalcommons.law.villanova.edu/vlr/vol57/iss3/5

This Symposia is brought to you for free and open access by Villanova University Charles Widger School of Law Digital Repository. It has been accepted for inclusion in Villanova Law Review by an authorized editor of Villanova University Charles Widger School of Law Digital Repository. 
Lederman: The U se of V oluntary Disclosure Initiatives in the BattleA gainst

\begin{tabular}{lllll}
\hline |ijciprod01 productn\VVLR\57-3\VLR305.txt & unknown & Seq: 1 & 27-NOV-12 & $10: 36$ \\
\hline
\end{tabular}

2012]

\title{
THE USE OF VOLUNTARY DISCLOSURE INITIATIVES IN THE BATTLE AGAINST OFFSHORE TAX EVASION
}

\author{
LEANDRA LEDERMAN*
}

\section{INTRODUCTION}

$\mathrm{T}$ HE individual income tax gap-the gap between taxes due and taxes timely and voluntarily paid-was recently estimated at $\$ 450$ billion for tax year 2006. ${ }^{1}$ That estimate does not break out international activity, ${ }^{2}$ but international tax noncompliance may be on the order of $\$ 100$ billion or more annually. ${ }^{3}$ The federal government is aware that some individuals make use of bank accounts in overseas jurisdictions with bank secrecy laws to evade federal taxes. ${ }^{4}$ Other U.S. taxpayers with offshore bank accounts may inadvertently fail to comply with U.S. tax laws, which include a requirement to report ownership of foreign accounts that have a balance of over $\$ 10,000$ during the year. ${ }^{5}$ Failure to report such an account gives rise

* William W. Oliver Professor of Tax Law, Indiana University Maurer School of Law, Bloomington, IN, llederma@indiana.edu. The author is grateful to Craig Boise, Leslie Book, Keith Fogg, Jordan Green, Susan Morse, and Bryan Skarlatos for helpful comments; to Dick Harvey, Tracy Kaye, David Walker, participants in the symposium, and participants in the 2012 Washburn Tax Colloquium for helpful discussions; and to Tyler Hawkins, Jennifer Hepp, and Michele Roberts for valuable research assistance.

1. See Tax Gap "Map" Tax Year 2006, I.R.S. (Dec. 2011), http://www.irs.gov/

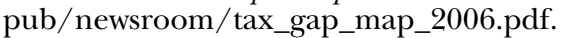

2. See id.; see also The Tax Gap and International Taxpayers, I.R.S. (Feb. 2008), http://www.irs.gov/Businesses/The-Tax-Gap-and-International-Taxpayers

("[T] here is currently no specific data to indicate what portion of the tax gap is attributable to international taxpayers . . . . Individual international taxpayers will be included in [the National Research Program] for the first time in 2008 with the examination of tax year 2006 returns."); TreAsury INSPECTOR GEN. FOR TAX ADmin., 2009-IE-R001, A Combination of Legislative Actions and Increased IRS Capability and Capacity Are Required to Reduce the Multi-Billion Dollar U.S. INTERNATIONAL TAX GAP (2009), available at http:/ /www.treasury.gov/tigta/ie reports/2009reports/2009IER001fr.html ("Non-IRS estimates of the international tax gap range from $\$ 40$ billion to $\$ 123$ billion. While there might be overlap between the IRS tax gap estimate and the international tax gap, it is doubtful that the $\$ 345$ billion estimate includes the entire international tax gap.”).

3. See Permanent Subcomm. on Investigations, Comm. on Homeland Sec. and Gov't Affairs, 110th Cong., Tax Haven Banks and U.S. Tax Compliance 1 (2008), available at http://hsgac.senate.gov/public/_files/071708PSIReport.pdf.

4. See id. at 1-2.

5. See 31 U.S.C. $\$ 5314$ (2006) ("Records and reports on foreign financial agency transactions."); 31 C.F.R. \$ 1010.350 (2011) ("Reports of foreign financial accounts."); Report of Foreign Bank and Financial Accounts (FBAR), I.R.S., http:/ / www. irs.gov/businesses/small/article/0, id=148849,00.html (last updated Mar. 5, 2012); Ellen Wallace, U.S. Versus Switzerland Over Bank Details: New Battle Round Opens (Update), Genevalunch.com (Sept. 5, 2011), http://genevalunch.com/ blog/2011/09/05/us-versus-switzerland-over-bank-details-new-battle-round-opensupdate ("The Fbar [sic] was originally designed as an anti-terrorism measure, but 
to information-return penalties, as well as to penalties on any unpaid taxes.

The tax penalties include accuracy, delinquency and fraud penalties that can range from $20 \%$ to $75 \%$ of the underpaid tax. In addition, there are penalties for failure to file or falsely filing information returns such as ... a Report of Foreign Bank Account ("FBAR"), and Forms 3520, 3520A, 5471, 5471, 926 and 8865. Some of these information return penalties can be quite large. For example, the penalty for willfully failing to file or falsely filing a FBAR can be $50 \%$ of the amount in the unreported account per year. ${ }^{6}$

Taxpayers who engage in intentional tax evasion typically do so by disguising their ownership of the offshore assets and failing to report on their tax returns ownership of the account or transactions in the account. The United States Senate Permanent Subcommittee on Investigations described several examples, including the following:

Mr. [Robert] Holliday [a client of a promoter who authored a how-to manual] transferred about $\$ 450,000$ in untaxed income to an Isle of Man shell corporation he controlled in payment for non-existent feasibility studies. To make use of the funds placed offshore, Mr. Holliday paid his bills using a credit card issued by an offshore bank, directed the offshore companies to pay designated expenses, and instructed [his] Nevada [shell] companies to borrow money from his offshore entities. These efforts allowed Mr. Holliday to conceal his income from the IRS, while enjoying control and use of the money. ${ }^{7}$

The federal government has engaged in a number of well-publicized enforcement efforts in an attempt to collect back taxes owed on funds in these accounts and encourage future compliance with the federal income

it has in the past two to three years surfaced as a tool to find assets that might have slipped through the net."). Some tax attorneys have commented that many of their clients had never heard of an FBAR before the government started cracking down on FBAR noncompliance. David D. Stewart, IRS Voluntary Disclosure Program Gets High Marks from Practitioners, So Far, Tax Notes Today, Sept. 3, 2009, at 169-3. Some foreign residents were unaware even that they were U.S. citizens and thus subject to U.S. tax laws. See IRS Clarifies Scope of Offshore Voluntary Disclosure Initiative Deadline Extension, Tax Notes Today, Aug. 31, 2011, at 169-18 (providing examples of this situation and guidance with respect to the 2011 Offshore Voluntary Disclosure Initiative).

6. Jodi J. Schwartz, NYSBA Tax Section Comments on FAQfor 2011 Offshore Voluntary Disclosure Initiative, Tax Notes Today, Aug. 9, 2011, at 153-13 (footnotes omitted).

7. Permanent Subcomm. on Investigations, Comm. on Homeland Sec. and Gov't Affairs, 109Th Cong., Tax Haven Abuses: The Enablers, the Tools and SECRECY 5 (2006), available at http://levin.senate.gov/imo/media/doc/supporting/2006/PSI.taxhavenabuses.080106.pdf. 
tax laws. ${ }^{8}$ Among those efforts are special "voluntary disclosure" initiatives run by the Internal Revenue Service (IRS), one of which ended in September $2011,{ }^{9}$ and another of which began in January 2012. ${ }^{10}$

Under a voluntary disclosure program, eligible taxpayers report their delinquent taxes in return for reduced penalties, a reduced likelihood of criminal prosecution upon detection of the evasion, or both. ${ }^{11}$ It is thus a form of "tax amnesty." 12 The 2012 offshore voluntary disclosure initiative is the third such program within the past few years. ${ }^{13}$

It is difficult to measure the success of a voluntary disclosure initiative because, in the year of its implementation, a voluntary disclosure program, like any tax amnesty, is a boon to the federal fisc. But government actions also create incentives. The tax amnesty literature recognizes the risk that amnesties, especially repeated ones, will encourage taxpayers to believe that they can evade taxes currently, then come in later and pay a dis-

8. See Internal Revenue Serv., IRS Fact Sheet FS-2012-6, IRS Releases 2006 TAx Gap Estimates (2012) [hereinafter FS-2012-6], available at http://www.irs. gov/pub/irs-news/fs-12-06.pdf (stating that "[s] topping offshore tax cheating and getting these people, especially high net-worth individuals, back into the tax system has been a top priority of the IRS" and listing as initiatives voluntary disclosure programs IRS conducted in 2009 and 2011, enforcement actions against foreign banks, and Foreign Account Tax Compliance Act (FATCA), Pub. L. No. 111-147, $\S \S 501-41,124$ Stat. 71, 97-117 (2010)).

9. See FS-2012-6, supra note 8. Originally, the deadline was August 31, 2011. See I.R.S. News Release IR-2011-14 (Feb. 8, 2011), available at http://www.irs.gov/ pub/irs-news/ir-11-014.pdf. However, it was extended to September 9, 2011 due to Hurricane Irene. OVDI Deadline Extended Due to Hurricane Irene, TAx Notes ToDAY, Aug. 26, 2011, at 167-45.

10. See I.R.S. News Release IR-2012-5 (Jan. 9, 2012), available at http://www. irs.gov/pub/irs-news/ir-12-005.pdf.

11. For example, the 2011 voluntary disclosure initiative states, "Taxpayers hiding assets offshore who do not come forward will face far higher penalty scenarios as well as the possibility of criminal prosecution." IR-2011-14, supra note 9.

12. See Craig M. Boise, Breaking Open Offshore Piggybanks: Deferral and the Utility of Amnesty, 14 Geo. Mason L. Rev. 667, 694 (2007) ("[A] typical tax amnesty offers tax evaders a window of opportunity within which to voluntary disclose their evasion in exchange for the reduction or elimination of penalties-either monetary or criminal.").

13. See IR-2012-5, supra note 10 ("The IRS reopened the Offshore Voluntary Disclosure Program (OVDP) following continued strong interest from taxpayers and tax practitioners after the closure of the 2011 and 2009 programs. The third offshore program comes as the IRS continues working on a wide range of international tax issues and follows ongoing efforts with the Justice Department to pursue criminal prosecution of international tax evasion."). Counting the 2003 voluntary disclosure initiative that grew out of the offshore credit card project would make the 2012 program the fourth in the last decade. For discussion of the 2003 initiative, see infra notes 30-44, and accompanying text. 
counted rate ${ }^{14}$-unless the amnesty is coupled with increased enforcement. $^{15}$

This Article examines the advisability of continued use of voluntary disclosure initiatives as a tool in the fight against international tax noncompliance. Part II of the Article briefly discusses the history of IRS voluntary disclosure programs, focusing particularly on the offshore initiatives of 2003, 2009, 2011, and 2012. In Part III, the Article evaluates the government's approach to voluntary disclosure of offshore evasion in light of the literature on optimal tax amnesties, finding that the offshore tax amnesties meet some but not all of the elements of an optimal amnesty. The Article concludes that the crackdown on offshore evasion has encouraged quite a number of taxpayers to make voluntary disclosures, but that the IRS's repeated use of offshore voluntary disclosure initiatives may have diminishing returns unless the government continues to engage in well-publicized criminal prosecutions of tax evaders.

\section{A Brief History of Voluntary Disclosure}

\section{A. Voluntary Disclosure Generally}

The IRS has a long history of encouraging voluntary disclosures of tax evasion. In 1919, the IRS had a policy not to criminally prosecute taxpayers making a voluntary disclosure. ${ }^{16}$ Although the policy was quickly amended to remove the commitment to forgo criminal prosecution, the IRS reinstituted that policy from 1945 to $1952 .{ }^{17}$ The IRS abandoned the policy again in 1952 partly because it allowed taxpayers to claim immunity from prosecution regardless of the context of their voluntary disclosure. ${ }^{18}$

Once the non-prosecution policy was withdrawn in January 1952, the IRS's official position was that voluntary disclosure was merely a factor to be considered in whether to recommend a taxpayer for criminal prosecution. ${ }^{19}$ In 1962, the advent of automatic processing of tax returns raised

14. See Herman B. Leonard \& Richard J. Zeckhauser, Amnesty, Enforcement, and Tax Policy, 1 Tax Pol'y \& Econ. 55, 55 (1987) ("Current amnesties may have encouraged some citizens to believe that there will be future amnesties as well, reducing their incentives to keep current on their payments.").

15. See id. at 65 ("A tax amnesty is almost inevitably coupled with increased penalties and enforcement efforts. ... If strong sanctions are prerequisites for maintenance of guilt and conscience ... then a tax amnesty could actually be part of a guilt-strengthening effort.").

16. See Bartholomew L. McLeay, Note, Disincentives to Voluntary Disclosure: United States v. Hebel and Deleet Merchandizing Corp. v. Commissioner, 3 VA. Tax Rev. 401, 403 (1984) (citing IRS Report on Role of Sanctions in Tax Compliance, History of Voluntary Disclosure Policy (Sept. 1968)).

17. See id. at 403-04 (reviewing history of voluntary disclosure policy).

18. See Gerald P. Moran, Tax Amnesty: An Old Debate as Viewed from Current Public Choices, 1 Fla. TAx REv. 307, 317 (1992) ("There was also some concern about possible corruption by government officials arising from the discretion inherent in the original policy.").

19. See McLeay, supra note 16, at 406 (citing I.R.S. News Release I.R. 61-432 (Dec. 13, 1961)); see also Moran, supra note 18, at 316-17 (discussing history of 
concerns on the part of some nonfilers that they would be detected. ${ }^{20}$ At that time, Commissioner Mortimer Caplin issued a news release stating, " $[\mathrm{T}]$ he question may arise whether a taxpayer's voluntary disclosure of his willful violations will afford immunity against criminal prosecution. I want to reaffirm our existing policy in this regard. Even true voluntary disclosure of a willful violation will not of itself guarantee prosecution immunity." ${ }^{21}$ Nonetheless, one commentator reports that "[d]espite the admonition that a voluntary disclosure did not immunize a taxpayer from criminal liability, an internal [IRS] memorandum disclosed that, at least from 1969 until 1974, the position of the Chief Counsel's Office was that a timely, good faith disclosure was 'dispositive' of the prosecution issue."22 In 1974, the IRS adopted a policy of considering the factors that triggered the taxpayer's disclosure. ${ }^{23}$

Currently, the Internal Revenue Manual (IRM) provides general voluntary disclosure provisions under the section titled Criminal Investigations-Other Investigations. ${ }^{24}$ The IRM provides that "a voluntary disclosure will be considered along with all other factors in the investigation in determining whether criminal prosecution will be recommended."25 It further states that:

A voluntary disclosure occurs when the communication is truthful, timely, complete, and when:

a. A taxpayer shows a willingness to cooperate (and does in fact cooperate) with the IRS in determining his/her correct tax liability, and

b. The taxpayer makes good faith arrangements with the IRS to pay in full, the tax, interest, and any penalties determined by the IRS to be applicable. ${ }^{26}$

It goes on to define what constitutes a timely disclosure. ${ }^{27}$ In general, in order to be "timely," a voluntary disclosure must occur before the taxpayer's noncompliance is on the IRS's radar. ${ }^{28}$

I.R.S. policy regarding waiving criminal prosecution in connection with a voluntary disclosure).

20. See Harry Graham Balter, Caplin Restates Voluntary Disclosure Policy as Rumors of IRS Change Circulate, $16 \mathrm{~J}$. TAX'N 104, 104 (1962).

21. Id. at 104.

22. McLeay, supra note 16, at 406.

23. See id. at 406-07.

24. See IRM 9.5.11.9 (2011), available at http://www.irs.gov/irm/.

25. Id. $\S 1$. The IRM further provides, "A voluntary disclosure will not automatically guarantee immunity from prosecution; however, a voluntary disclosure may result in prosecution not being recommended. This practice does not apply to taxpayers with illegal source income." Id. $\$ 2$ (emphasis added).

26. Id. $\$ 3$ (emphasis added).

27. See id. $\S 4$.

28. More precisely, the IRM provides:

A disclosure is timely if it is received before: 
In addition to this general voluntary disclosure regime, the IRS also periodically offers targeted voluntary compliance initiatives. For example, it offered one in 1992 for nonfilers. ${ }^{29}$ With respect to offshore tax evasion, the IRS has offered a series of programs in the last decade. Each of these was connected with publicity about a crackdown on offshore evasion.

\section{B. Voluntary Disclosure of Offshore Tax Evasion}

The first of the offshore voluntary disclosure initiatives was in 2003. That initiative was related to an offshore credit card project the IRS pursued starting in 2000. ${ }^{30}$ That project involved serving "John Doe" summonses on major credit card companies, such as MasterCard and American Express, seeking records on foreign bank accounts. ${ }^{31}$ For example:

On October 30, 2000, a U.S. District Court in Miami, Florida, authorized the IRS to issue John Doe summonses to MasterCard International and American Express. These summonses relate to accounts in Antigua, Barbuda, the Bahamas, and the Cayman Islands issued to U.S. customers for tax years 1998 and 1999. These John Doe summonses were designed to allow the IRS to secure information from a reasonably identifiable group-U.S.based customers with credit card accounts in certain foreign countries-who may be using offshore bank accounts to evade U.S. taxes. ${ }^{32}$

A. The IRS has initiated a civil examination or criminal investigation of the taxpayer, or has notified the taxpayer that it intends to commence such an examination or investigation.

B. The IRS has received information from a third party (e.g., informant, other governmental agency, or the media) alerting the IRS to the specific taxpayer's noncompliance.

C. The IRS has initiated a civil examination or criminal investigation which is directly related to the specific liability of the taxpayer.

D. The IRS has acquired information directly related to the specific liability of the taxpayer from a criminal enforcement action (e.g.,

Id. search warrant, grand jury subpoena).

29. See Moran, supra note 18, at 318 ("On September 30, 1992, the Internal Revenue Service issued a notice announcing the adoption of a special program to provide comprehensive support for the ten million nonfilers.").

30. See Treasury Inspector Gen. for Tax Admin., 2003-30-160, The Offshore Credit Card Project Shows Promise, but Improvements Are Needed to Ensure That Compliance Objectives Are Achieved (2003) [hereinafter 2003-30160], available at http://www.treasury.gov/tigta/auditreports/2003reports/200330 $160 \mathrm{fr} . \mathrm{html}$.

31. See id; see also Paul Jensen \& Pam Spikes, Offshore Credit Card Records: Invasion By the IRS, 29 InT'L TAX J. 59, 59 (2003). A John Doe summons does not name the taxpayer whose liability is in issue. See I.R.C. $\$ 7609$ (f) (2006).

32. Josh O. Ungerman, Voluntary Disclosure and IRS Attacks on Offshore Credit Cards, 4 Corp. Bus. TAx'n Monthly 3, 3 (2003) (footnote omitted). 
In 2002, the IRS served additional summonses on MasterCard International and Visa International. ${ }^{33}$

The summonses produced a substantial amount of data, ${ }^{34}$ but the data was not very complete. "The cardholder records obtained from the credit card companies did not include cardholder identifiers such as name or Social Security Number. In addition to the cardholder records from the John Doe summonses . . . the IRS issued merchant summonses for charge card transactions, which helped identify specific taxpayers." 35 After collecting the information from the John Doe summonses, the IRS revised downward its estimate of how many credit card holders were involved. ${ }^{36}$

Professor Keith Fogg explains that taking enforcement action based on the information obtained from the John Doe Summonses proved institutionally difficult for the IRS. For one thing, the "influx of data created a situation in which the IRS could not realistically pursue all of the individuals suspected of offshore credit card ownership." 37 For another,

By the time the IRS gathered enough data to place cases in the hands of revenue agents, the cases were much older than "normal" cases placed into the audit stream. This meant that agents were receiving cases that would almost certainly have the threeyear statute of limitations on assessment expire before the agents could complete their audits. Revenue agents receive much training and instruction on the importance of not allowing a statute of limitations to expire. Receipt of cases that almost by definition required them to complete a blown statute report did not sit well with the agents as a group or their managers. ${ }^{38}$

Around the time of the service of the John Doe summonses, ${ }^{39}$ " $[\mathrm{i}] \mathrm{n}$ February 2003, the IRS announced its 'Offshore Voluntary Compliance

33. Id.

34. See Internal Revenue Serv., IRS Fact Sheet FS-2002-12, IRS Sets New Audit Priorities (Sept. 2002), available at http://www.irs.gov/pub/irs-news/fs-0212.pdf ("The first summons alone yielded data from MasterCard on 237,000 cards issued through 28 banks in three countries.").

35. 2003-30-160, supra note 30 (footnote omitted).

36. I.R.S. News Release IR-2003-5 (Jan. 14, 2003), available at www.irs.gov/ pub/irs-news/ir-03-05.pdf [hereinafter IR-2003-5] (explaining that IRS found "duplicate cards issued to the same individual, inactive or small-dollar accounts, people using the cards because of bad credit, persons traveling abroad and a wide range of other non-tax reasons for holding the cards").

37. Keith Fogg, Go West: How The IRS Should Foster Innovation in Its Agents, 57 Vill. L. Rev. 441, 463 (2012).

38. Id. at 462. He added, "[R] evenue agents with these cases generally needed ... to mak [e] a fraud case . . . in order to keep the statute of limitations on assessment open." Id. The government bears the burden of proving fraud. See I.R.C. $\$ 7454(\mathrm{a})(2006)$.

39. See Fogg, supra note 37, at 464 ("The initial wave of credit card summonses occurred from October 2000 through December 2003.”). 
Initiative,' [(OVCI)] a program designed to allow taxpayers to step forward and 'clear up their tax liabilities." "40 It provided that the IRS would, "in appropriate circumstances, impose the delinquency penalty under section 6651 , the accuracy-related penalty under section 6662 , or both penalties against taxpayers that participate in the Offshore Voluntary Compliance Initiative." 41 The program waived the fraud penalty, the fraudulent failure-to-file penalty, and certain information return penalties otherwise applicable to participating taxpayers. ${ }^{42}$ In addition, participating taxpayers would not be criminally prosecuted. ${ }^{43}$

The IRS directly linked the offshore credit card project and the voluntary disclosure initiative:

OVCI is just one part of an on-going, multi-pronged effort by the IRS to counter offshore tax evasion.

A related, but separate component of the effort is the Offshore Credit Card Program (OCCP). This program stems from the John Doe summons investigation. Since October 2000, the IRS has issued a series of summonses to a variety of financial and commercial businesses to obtain information on residents who held credit, debit or other payment cards issued by offshore banks.

Investigators have been using records from the John Doe summonses to trace the identities of people whose use of these payment cards may be related to hiding taxable income.

....

In the weeks and months ahead, the IRS will continue working on the OVCI and OCCP programs. As part of this process, the IRS will continue its work to identify and pursue civil and/or criminal penalties against those engaged in improper offshore transactions. ${ }^{44}$

The 2003 voluntary disclosure initiative had an April 15 deadline, ${ }^{45}$ but, in June 2003, the IRS sent over 600 "last chance" letters to taxpayers it had identified as having offshore credit cards, offering them an opportu-

40. Ungerman, supra note 32, at 4 (quoting IR-2003-5, supra note 36).

41. Rev. Proc. 2003-11, 2003-1 C.B. 311 2.01(2), available at http://www.irs. gov/pub/irs-drop/rp-03-11.pdf.

42. See id. $\$ 2(1)$ ("[T] he Service . . . will not impose the civil fraud penalty under section 6663, the fraudulent failure to file penalty under section 6651(f), and information return civil penalties for failure to comply with sections 6035 , 6038, 6038A, 6038B, 6038C, 6039F, 6046, 6046A, and 6048"); see also IR-2003-5, supra note 36 .

43. See I.R.S. News Release IR-2003-95 (July 30, 2003) [hereinafter IR-200395], available at http://www.irs.gov/pub/irs-news/ir-03-95.pdf; see also IR-2003-5, supra note 36.

44. IR-2003-95, supra note 43.

45. See Rev. Proc. 2003-11, 2003-1 C.B. 311 § 3.01, available at http://www.irs. gov/pub/irs-drop/rp-03-11.pdf. 
nity to participate in the program. ${ }^{46}$ The 2003 initiative had some modest success, but less than the IRS initially thought. In July 2003, the IRS reported:

[C] urrent results show the initiative's effectiveness:

- Taxpayers have already paid more than $\$ 75$ million in taxes to the program.

- The $\$ 75$ million figure will continue to grow because most taxpayers accepted into the program have until Oct. 15 to amend their tax returns and pay back taxes.

- OVCI applicants identified more than 400 offshore promoters. Of these, 214 promoters were previously unknown to the IRS, which helps the agency's efforts to counter offshore tax evasion.

- While the program has led to $\$ 75$ million in taxes collected, the cost of the OVCI program is approximately $\$ 2$ million to date. ${ }^{47}$

Subsequently, however, an investigation by the Treasury Inspector General for Tax Administration (TIGTA) undermined those results:

The IRS initially believed that upwards of $\$ 100$ million in identified unpaid taxes were available for assessment. As of June 30, 2003 , the IRS assessed only $\$ 3.3$ million with only $\$ 744,546$ having been collected. According to TIGTA, the largest assessment was for $\$ 375,000 \ldots$ TIGTA also reported that the cost of the OVCI project has been estimated at $\$ 56$ million. ${ }^{48}$

The credit card initiative had limited success largely because the IRS was not prepared to audit all of the individuals it identified who did not participate in the voluntary disclosure initiative. ${ }^{49}$ However, the IRS did

46. See Government Accountability Office, GAO Audits IRS FY 2003 and 2004 Financial Statements, Tax Notes Today, Nov. 17, 2003, at 221-58; Martin A. Sullivan, Economic Analysis: Keeping Score on Offshore: U.K. 60,000, U.S. 1,300, 116 TAx Notes 23, 26 (2007).

47. IR-2003-95, supra note 43.

48. Charles E. Grassley \& Max Baucus, Finance Leaders Request "Prompt" Review of Offshore Compliance Initiative, TAx Notes Today, July 29, 2003, at 146-22.

49. See Joint Comm. on Taxation, JCT Describes Compliance Issues Affecting Offshore Accounts, Tax Notes Today, Apr. 1, 2009, at 60-15 "'Then IRS Commissioner Mark Everson discussed the limited success of the OVCI initiative at a . . hearing on August 1, 2006. Within his testimony, he stated 'In reality, we did not have a good idea of the potential universe of individuals covered by this initiative. As a result, the incentive for taxpayers to come forward and take advantage of this initiative was diminished due to the fact that we did not have the ability to identify immediately and begin examinations for all non-participating individuals." (quoting Written Testimony of Commissioner of Internal Revenue Mark Everson Before Senate Committee on Homeland Security and Governmental Affairs' Permanent Subcommittee on Investigations Hearing on Offshore Abuses: The Enablers, The Tools and Offshore Secrecy, 109th Cong., August 1, 2006)). 
identify over 400 promoters of abusive offshore financial arrangements. ${ }^{50}$ It also referred a few dozen cases to the Criminal Investigation Division for prosecution prior to the voluntary disclosure deadline..$^{51}$

A number of years went by before the IRS's next voluntary disclosure initiative, which took place in 2009. That initiative was also in conjunction with a crackdown on offshore evasion. The crackdown focused on Swiss bank accounts, particularly those held at Union Bank of Switzerland (UBS):

Strained relations between Switzerland, a country with a long tradition of bank secrecy, and the United States began during the summer of 2008 when a disgruntled former UBS employee, code name Tarantula revealed that "he was part of a UBS team that made frequent trips across the Atlantic [to the United States] to aggressively market investment strategies to rich Americans" to evade the IRS. ${ }^{52}$

"Tarantula" was Bradley Birkenfeld, a UBS "private banker." 53 Birkenfeld's job had been to prospect for American clients. ${ }^{54}$ The Justice Department indicted him in $2008,{ }^{55}$ and he pled guilty to helping an American billionaire evade federal income taxes. ${ }^{56}$

Birkenfeld's arrest prompted the Justice Department to investigate UBS. ${ }^{57}$ In June 2008, the Justice Department:

[F]iled a petition in the U.S. District Court for the Southern District of Florida requesting leave to file an IRS administrative summons with UBS asking the bank to disclose the names of all of its U.S. clients who have opened accounts in Switzerland, but for which the bank has not filed forms with the IRS disclosing the Swiss accounts. The court approved service of the summons on

50. See id.

51. See Internal Revenue Serv., IRS Release on Offshore Credit Cards, Tax Notes TODAY, Mar. 13, 2003, at 50-8.

52. Jared Seff, Cracking Down on Tax Evaders-Swiss Banking: Secrets, Lies, and Deception, 38 S.U. L. Rev. 159, 160 (2010) (alteration in original) (citing Graham Bowley, A Privileged World Begins to Give up Its Secrets, N.Y. Times, Aug. 23, 2009, at WK3).

53. See id. Birkenfeld was Tax Analysts' 2009 Person of the Year. See Year in Review: The 2009 Person of the Year, Tax Notes Today, Jan. 4, 2010, at 1-3.

54. See Evan Thomas \& Mark Hosenball, Cracking the Vault, Newsweek, Mar. 13, 2009, available at http://www.thedailybeast.com/newsweek/2009/03/13/ cracking-the-vault.html.

55. See Stewart, supra note 5. Birkenfeld was arrested in May 2008 when he returned to the U.S. from Switzerland to attend his 25th high school reunion. See Year in Review: The 2009 Person of the Year, supra note 53 (also noting that "Birkenfeld did not obtain immunity from prosecution in exchange for his disclosures" about UBS's actions).

56. See Lynnley Browning, Ex-UBS Banker Pleads Guilty in Tax Evasion, N.Y. Times, June 20, 2008, at C1.

57. Seff, supra note 52, at 162. 
UBS on July 1, 2008. . . This John Doe summons represents the first time that the United States has attempted to pierce Swiss bank secrecy by compelling a Swiss bank to name its U.S. clients. ${ }^{58}$

In 2009, the U.S. government charged UBS with conspiring to defraud the United States by assisting accountholders in evading the IRS. ${ }^{59}$ In February 2009, UBS signed a deferred prosecution agreement. "[U]nder the terms of the agreement, UBS will provide the U.S. government with the names of 200 to 300 U.S. clients of UBS's cross-border business, exit the business of providing banking services to U.S. clients with undeclared accounts, and pay a total of $\$ 780$ million in fines and penalties." 60

At that time, UBS had not yet responded to the John Doe summons, so the U.S. government filed a petition in district court to enforce the summons. ${ }^{61}$ UBS objected, citing Swiss bank secrecy law among its reasons. ${ }^{62}$ The Swiss government stepped in, filing an amicus brief arguing that the United States could only obtain accountholder information via a request under the 1996 U.S.-Swiss tax treaty. ${ }^{63}$ In August 2009, the United States and Switzerland reached an agreement to treat the request as occurring under the treaty, as well as to sign a protocol amending the treaty and to have the U.S. government withdraw the John Doe summons. ${ }^{64}$ Under the agreement, the U.S. government received the names of 4,450 U.S. UBS account holders. ${ }^{65}$

58. Staff of Permanent S. Comm. on Investigations, Comm. on Homeland Sec'y and Governmental Affairs, 110th Cong., Staff Rep., Tax Haven Banks AND U.S. TAx Complance 3 (2008), available at http://www.levin.senate.gov/imo/ media/doc/supporting/2008/071708PSIReport.pdf (footnotes omitted).

59. DOJ Announces Deferred Prosecution Agreement with UBS, Tax Notes Today, Feb. 19, 2009, at 31-32.

60. Laura Szarmach, Note, Piercing the Veil of Bank Secrecy? Assessing the United States' Settlement in the UBS Case, 43 Cornell InT'L L.J. 409, 411 (2010).

61. See id.

62. See id. Swiss bank secrecy focuses on protecting the financial information of accountholders. See Urs Martin Lauchli, Swiss Bank Secrecy with Comparative Aspects to the American Approach, 42 ST. Louis U. L.J. 865, 865 (1998) ("The Swiss approach to bank secrecy, simply stated, protects the right of bank customers to have their financial information remain confidential and enforces the banker's duty to safeguard that right. If bankers fail in this duty, they are subject to criminal sanctions.").

63. See Szarmach, supra note 60, at 411.

64. See Agreement on the Request for Information from the Internal Revenue Service of the United States of America Regarding UBS AG, a Corporation Established Under the Laws of the Swiss Confederation, U.S.-Switz., art. 1-3, Aug. 19, 2009, available at http://www.justice.gov/opa/documents/us-swiss-agreement.pdf; see also Szarmach, supra note 60, at 411.

65. Wallace, supra note 5. Tax attorney Charles Rettig explained:

The criteria included the disclosure of accounts at UBS between 2001 and 2008 with a balance of more than 1 million Swiss francs, together with various types of custody accounts (including bank-only ac- 
Right around this time, in March 2009, the IRS announced the 2009 voluntary disclosure initiative for offshore tax evasion. ${ }^{66}$ Under the initiative, participating taxpayers were required to pay taxes and interest due on amounts in the account for the previous six years; either an accuracy-related penalty or a delinquency penalty on each of those six years; and a penalty of $20 \%$ on the highest account or asset value in that six-year period. ${ }^{67}$ The program also required participants to disclose information about their foreign accounts, including the names of the financial institutions they used and the names of their contacts at those institutions. ${ }^{68}$

The 2009 initiative was timed to profit from the publicity about Birkenfeld and UBS: "Following the announcement in May 2008 that the Justice Department had indicted former UBS banker Bradley Birkenfeld, the IRS voluntary disclosure program saw a dramatic rise in taxpayers coming forward to turn over information on previously undisclosed Swiss bank accounts." 69 The 2009 initiative brought in about 15,000 disclosuresmany times more than the approximately 1,000 that the IRS reportedly expected. ${ }^{70}$ In early 2012, the IRS reported that it had "collected $\$ 3.4$ billion so far from people who participated in the 2009 offshore program, reflecting closures of about 95 percent of the cases from the 2009 program." 71

counts) in which securities or other investment assets were held, and offshore company nominee accounts through which individuals indirectly held beneficial ownership.The disclosure criteria also included (i) 250 accounts in which there is evidence of "fraudulent conduct," such as false documents or the use of calling cards to disguise the source of trading (the threshold for disclosure is 250,000 francs), and (ii) 4,200 accounts that generated revenues of an average of more than 100,000 francs a year for at least three years, including any year between 20012008.

Charles P. Rettig, Evaluation of an IRS Undisclosed Offshore Account IDR, TAx Notes ToDAY, Sept. 30, 2011, at 217-12.

66. See Kristen A. Parillo \& Jeremiah Coder, IRS Reduces Penalties on Voluntarily Disclosed Offshore Accounts, Tax Notes Today, Mar. 27, 2009, at 57-2.

67. See id.; see also Internal Revenue Serv., IRS Issues Memorandum Outlining Penalty Structure for Voluntary Disclosure, TAx Notes Today, Mar. 27, 2009, at 57-34 [hereinafter IRS Issues Memorandum]; Internal Revenue Serv., IRS Releases FAQ on Voluntary Disclosure Program for Offshore Accounts, Tax Notes Today, May 7, 2009, at 86-14 [hereinafter IRS Releases 2009 FAQ] ("The twenty percent penalty applies to all assets (or at least the taxpayer's share) held by foreign entities (e.g., trusts and corporations) for which the taxpayer was required to file information returns, as well as all foreign assets (e.g., financial accounts, tangible assets such as real estate or art, and intangible assets such as patents or stock or other interests in a U.S. business) held or controlled by the taxpayer.").

68. See Rettig, supra note 65.

69. Stewart, supra note 5.

70. Shulman Addresses IRS's Strategic Priorities for the Future, Tax Notes Today, May 19, 2011, at 97-11 (releasing prepared remarks of I.R.S. Commissioner Douglas Shulman) [hereinafter Strategic Priorities].

71. IR-2012-5, supra note 10. 
After 2009, the government continued to focus on pursuing offshore tax evasion. The IRS mined the data it received from the 2009 initiative. ${ }^{72}$ The government continued to prosecute UBS clients. ${ }^{73}$ In early 2012, it also indicted three private bankers from the Swiss bank Wegelin \& Co. ${ }^{74}$ and a number of Credit Suisse bankers in the United States. ${ }^{75}$ The government also requested from other Swiss banks, including Credit Suisse, the names of U.S. account holders. ${ }^{76}$

In another widely publicized move, HSBC [a London-based banking and financial services organization] ended its foreign banking services for its wealthiest U.S.-resident customers. United States residents will now be served only by the bank's wealth management division through its U.S. branch. The news came shortly after the DOJ announced an indictment implicating HSBC India. ${ }^{77}$

The U.S. government has also received information about offshore evasion from whistleblowers. ${ }^{78}$ Bradley Birkenfeld, who applied for

72. See Rettig, supra note 65.

73. See Offshore Tax-Avoidance and IRS Compliance Efforts, I.R.S., http://www.irs. gov/uac/Offshore-Tax-Avoidance-and-IRS-Compliance-Efforts (last reviewed or updated Aug. 1, 2012) (listing UBS clients who were prosecuted and legal actions to date).

74. See David D. Stewart, 3 Swiss Bankers Indicted for Hiding \$1.2 Billion, Tax Notes Today, Jan. 5, 2012, at 3-2 ("In its case before the U.S. District Court for the Southern District of New York, the Justice Department alleged that Michael Berlinka, Urs Frei, and Roger Keller helped conceal more than $\$ 1.2$ billion in assets for U.S. clients. The government claims that the defendants used a website to solicit U.S. clients and sought to attract UBS customers whose accounts were scheduled to be closed after that bank announced that it was closing its U.S.-held offshore accounts as it faced investigations in the United States.").

75. See Marie Sapirie, Practitioners Assess Offshore Initiative as Deadline Approaches, TAx Notes Today, Aug. 15, 2011, at 157-1.

76. See id. After this request, Credit Suisse started informing "its U.S. private banking clients that their information is subject to disclosure under a treaty request made by the U.S. authorities." See David D. Stewart, Credit Suisse Preparing to Report Client Data to U.S., Tax Notes Today, Nov. 9, 2011, at 217-8. However, the Swiss Federal Administrative Court in Bern recently upheld an accountholder's appeal, relying on the distinction under Swiss law between tax fraud, for which information exchange exists under the 1996 U.S.-Swiss treaty, and tax evasion, for which it does not. See David Jolly, Swiss Court Ruling Hampers a Tax Deal, N.Y. Times, Apr. 11, 2012, at B5.

77. Sapirie, supra note 75.

78. See Marie Sapirie, New Offshore Voluntary Disclosure Initiative Features 25 Percent Penalty, Greater Clarity, Tax Notes Today, Feb. 9, 2011, at 27-1. 
whistleblower status, ${ }^{79}$ was successfully prosecuted. ${ }^{80}$ However, practitioners have said that Birkenfeld's prosecution had only "a 'slight chilling effect' on other would-be informants." 1

In 2010, as another line of attack on offshore tax evasion, the federal government enacted the Foreign Account Tax Compliance Act (FATCA), as part of the Hiring Incentives to Restore Employment (HIRE) Act. ${ }^{82}$ In part, FATCA requires taxpayers to disclose foreign financial assets aggregating in excess of a financial threshold. ${ }^{83}$ The disclosure must be made in a statement attached to the taxpayer's return; the IRS released Form 8938 for this purpose. ${ }^{84}$ This requirement may overlap with the FBAR, but it has a higher reporting threshold and includes non-cash assets. ${ }^{85}$

FATCA also imposes obligations on foreign banks, requiring them to withhold $30 \%$ on United States-sourced payments to foreign financial institutions unless the bank enters into an information-disclosure agreement with the Secretary of the Treasury. ${ }^{86}$

Because the choice to withhold rather than report is an institution-wide one, foreign banks with clients from different countries have an incentive to comply with FATCA, especially if some of

79. See David D. Stewart, Attorney in UBS Scandal Sees Reward Claim as Test of U.S. Whistle-blower Policy, Tax Notes Today, Dec. 7, 2009, at 232-4 ("Dean Zerbe, national managing director for Alliantgroup and special counsel to the National Whistleblowers Center, discussed Birkenfeld's claim in a December 3 interview. Zerbe explained that Birkenfeld filed a whistle-blower claim early on in the process of his cooperation with the IRS. He said that his role is to 'perfect' Birkenfeld's claim.”).

80. National Whistleblowers Center Takes Issue with DOJ Prosecution of UBS Whistleblower, TAx Notes Today, Apr. 8, 2010, at 67-30 ("The DOJ not only did not credit Mr. Birkenfeld with disclosure of the scandal, it actively prosecuted him. In other words, the bad guy was let go and the good guy is in jail." (quoting statement by NWC Executive Director Stephen M. Kohn)).

81. Marie Sapirie, New Era of International Enforcement Follows UBS, TAx Notes Today, Aug. 10, 2011, at 154-2 (quoting Scott D. Michel of Caplin \& Drysdale).

82. See Christopher M. Reimer, The Undiscovered Country: Wyoming's Emergence as a Leading Trust Situs Jurisdiction, 11 Wyo. L. Rev. 165, 169 (2011); see also Hiring Incentives to Restore Employment Act, Pub. L. No. 111-147, §§ 501-41, 124 Stat. 71, 97-117 (2010).

83. See I.R.C. $\$ 6038 D$ (West 2010) (providing for threshold of $\$ 50,000$, or higher amount determined by the Treasury Department); Temp. Treas. Reg. $\$ 1.6038 \mathrm{D}-2 \mathrm{~T}(\mathrm{a})$ (2011) (providing thresholds ranging from $\$ 50,000$ to $\$ 600,000$, depending on marital status and whether taxpayer lives in United States or abroad).The reporting requirement "is effective for tax years starting after March 18, 2010, which for most people will be their 2011 tax returns filed during the 2012 filing season." IRS Releases Information Detailing Regs, Filing Requirements for Reporting Foreign Financial Assets, Tax Notes Today, Dec. 16, 2011, at 242-25.

84. See I.R.S. Form 8938 (Nov. 2011), available at http://www.irs.gov/pub/irspdf/f8938.pdf.

85. See Marie Sapirie, Foreign Financial Asset Reporting Regs Broad in Scope, TAx Notes Today, Dec. 16, 2011, at 242-2.

86. See Niels Jense, Note, How to Kill the Scapegoat: Addressing Offshore Tax Evasion with a Special View to Switzerland, 63 VAND. L. REv. 1823, 1849-50 (2010). 
their non-U.S. clients would be taxed at less than thirty percent on their investment income or are evading their home country's taxes completely. By choosing not to disclose under FATCA, a foreign financial institution in essence subjects all of its customers to a thirty percent tax on U.S. income. Since such a uniform tax may scare away clients, foreign banks have a strong incentive to comply. Although U.S. clients will lose their privacy protection, the institution's other clients will remain unaffected by the institution's compliance-they can continue to enjoy favorable tax treatment by the United States, while possibly avoiding their home countries' taxes. ${ }^{87}$

The effective date of this part of FATCA was recently extended, so that withholding obligations will begin in $2014 .^{88}$

Professor Morse explains that the withholding requirement may not really be enforceable. ${ }^{89}$ Nonetheless, and although it has not yet taken effect, this portion of FATCA has already had an impact:

The reporting and withholding requirements of the Foreign Account Tax Compliance Act have stung some U.S. taxpayers who live abroad: They have found themselves being unceremoniously dumped by their local banks in anticipation of what Scott D. Michel, a partner at Caplin \& Drysdale, referred to as the coming "era of automatic disclosure." 90

Despite the highly publicized crackdown on offshore evasion in 2009, some eligible taxpayers did not take advantage of the 2009 voluntary dis-

87. Id. at 1850 .

88. See I.R.S. Notice 2011-53, 2011-32 I.R.B. 124 (“[Planned] regulations will provide that certain obligations of participating FFIs [Foreign Financial Institutions] will commence in 2013. Further, those regulations will provide that the section 1471(a) and section 1472(a) withholding obligations of withholding agents with respect to amounts described in section 1473(1)(A)(i) (U.S. source FDAP payments) will begin on January 1, 2014.").

89. Susan C. Morse, Ask for Help, Uncle Sam: The Future of Global Tax Reporting, 57 ViLL. L. REv. 529, 537 (2012) (explaining that "imposing a withholding tax could ... require the commitment of international relations resources" and "produce unwanted capital market disruptions" and that "the United States lacks the jurisdiction to confirm directly that FFIs are in fact complying with their obligations under their agreements"). She suggests ways in which the United States government might maximize its enforcement of FATCA. See id. at 542-49.

90. Sapirie, supra note 75. Professor Morse explains:

$[\mathrm{N}]$ on-U.S. FFIs might embrace compliance with FATCA as a positive reputational signal to clients and governments. This signal might grow in strength as more banks comply with the FATCA and as compliant banks increasingly commit to FATCA compliance through their very acts of due diligence and reporting. There are certain choices that U.S. policymakers can make to maximize the chance that FATCA will succeed as a reputational strategy. .. But the success of this approach is far from certain.

Morse, supra note 89 , at 537-38. 
Villanova Law Review, Vol. 57, Iss. 3 [2012], Art. 5

\begin{tabular}{lllll}
\hline liciprod01 productn\VVLR $57-3 \backslash V L R 305 . t x t$ & unknown & Seq: 16 & 27-NOV-12 & $10: 36$ \\
\hline
\end{tabular}

closure initiative. Some made voluntary disclosures under the general policy. ${ }^{91}$ Other taxpayers came in "quietly"-simply amending old returns and paying back taxes and interest, ${ }^{92}$ an approach the government discouraged..$^{93}$

Given the continuing volume of taxpayers coming in to disclose noncompliance regarding offshore accounts after the close of the 2009 initiative, ${ }^{94}$ the government perceived a need for another voluntary disclosure program. ${ }^{95}$ Accordingly, on February 8 , 2011, the IRS announced the

91. See IRS Releases FAQ on Second Offshore Voluntary Disclosure Program, TAx Notes TodAy, Feb. 9, 2011, at 27-19 [hereinafter IRS Releases 2011 FAQ] ("Is a taxpayer who previously sought relief under the IRS's traditional Voluntary Disclosure Practice or who made a quiet disclosure before the 2011 OVDI was announced eligible for the terms of the 2011 OVDI?").

92. See IRS Releases 2009 FAQ, supra note 67 ("The IRS is aware that some taxpayers have attempted so-called 'quiet' disclosures by filing amended returns and paying any related tax and interest for previously unreported offshore income without otherwise notifying the IRS.").

93. See Jeremiah Coder, U.S. Gaining on Offshore Accounts, IRS Officials Say, TAx Notes Today, Nov. 17, 2009, at 219-7 ("Arlette Lee, a special agent in the IRS Criminal Investigation division .... . [W] arned that trying to make a quiet disclosure to avoid directly putting the government on notice of unreported offshore accounts could result in charges of tax evasion and filing a false tax return. 'We want people to come through the program; if you don't and take another route, this is what you potentially could be facing if we find out about you,' she said."); Bank Director Charged with Hiding Foreign Assets, Used Offshore Account to Conceal Income from IRS, DEP'T OF Justice (May 19, 2011), http://www.justice.gov/opa/pr/ 2011/May/11-tax-642.html ("On its website, the IRS strongly encourages taxpayers to come forward under the Offshore Voluntary Disclosure Program and warns them that taxpayers who instead make silent disclosures risk being criminally prosecuted for all applicable years.").At least one taxpayer who made a quiet disclosure was prosecuted. See id. ("According to the criminal information and plea agreement, on Oct. 6, 2009, following widespread media coverage of UBS's disclosure to the IRS of account records for undeclared accounts held by U.S. taxpayers and the IRS's Voluntary Disclosure Program, [Michael] Schiavo made a 'silent disclosure' by preparing and filing FBARs and amended Forms 1040 for tax years 2003 to 2008 , in which he reported the existence of his previously undeclared account at HSBC Bank Bermuda.”). However, according to the indictment, Mr. Schiavo did not amend his 2006 return to report a taxable payment he had received until after an IRS special agent contacted him. See Bank Director Charged with Failure to Report Interest in Foreign Bank Account TAx Notes TodAY, May 23, 2011, at 99-21 (discussing United States v. Schiavo, No. 11-10984 (D. Mass. 2011)).

94. See Strategic Priorities, supra note 70 (“[S]ince [the 2009 initiative] closed, we've received an additional 4,000 voluntary disclosures from individuals with secret bank accounts from around the world."); Paul Sullivan, Voluntarily Disclose Your Offshore Accounts, or Else, N.Y. Times, Aug. 27, 2011, at B5 (“[A]fter [the 2009 program] officially ended, thousands more came forward, flooding the I.R.S. enforcement system.").

95. See Sullivan, supra note 94 ("[I]t made sense from an I.R.S. perspective to offer a second round of disclosure...." given the continuing volume of disclosures after the 2009 program closed); see also IRS Clarifies Scope of Offshore Voluntary Disclosure Initiative Deadline Extension, supra note 5 ("The IRS's prior Offshore Voluntary Disclosure Program . . ., which closed on October 15, 2009, demonstrated the value of a uniform penalty structure for taxpayers who came forward voluntarily and reported their previously undisclosed foreign accounts and assets. . . . [I]t was 
2011 Offshore Voluntary Disclosure Program (OVDI). "The roughly 3,000 taxpayers who came forward after the [2009 program] ended will be eligible for the terms of the new OVDI."96

Under the 2011 OVDI, individuals voluntarily disclosing offshore bank accounts owed a 25 percent penalty on the highest aggregate account or asset balance from the years 2003-2010. ${ }^{97}$ For those who have offshore accounts totaling less than $\$ 75,000$, the penalty was reduced to $12.5 \%{ }^{98}$ Taxpayers could also qualify for a $5 \%$ penalty if (1) they did not open the account, (2) had minimal contact with the account, (3) did not withdraw more than $\$ 1000$ in any year covered by the OVDI, and (4) could establish that taxes were paid on the amounts they deposited. ${ }^{99}$ Foreign residents who did not know they were U.S. citizens could also receive the $5 \%$ penalty. ${ }^{100}$ Participants in the OVDI program also had to pay back taxes and interest for up to eight years as well as paying applicable accuracy-related penalties, delinquency penalties, or both. ${ }^{101}$ The program waived other penalties, including criminal prosecution. ${ }^{102}$ The program was scheduled to expire on August 31, 2011, but was extended to September 9, 2011, due to Hurricane Irene. ${ }^{103}$

The 2011 program thus had a longer look-back period than the 2009 initiative did-eight years rather than six - so, taxpayers who did not participate in 2009 but did in 2011 did not get a "pass" with respect to the 2003 and 2004 tax years. This also means that the period included is

determined that a similar initiative should be available to the large number of taxpayers with offshore accounts and assets who applied to IRS Criminal Investigation's traditional voluntary disclosure practice since the October 15 deadline.”).

96. Sapirie, supra note 78.

97. See IR-2011-14, supra note 9; IRS Releases 2011 FAQ, supra note 67. The latter document explains:

The offshore penalty is intended to apply to all of the taxpayer's offshore holdings that are related in any way to tax non-compliance. . . . The penalty applies to all assets directly owned by the taxpayer, including financial accounts holding cash, securities or other custodial assets; tangible assets such as real estate or art; and intangible assets such as patents or stock or other interests in a U.S. or foreign business. If such assets are indirectly held or controlled by the taxpayer through an entity, the penalty may be applied to the taxpayer's interest in the entity or, if the Service determines that the entity is an alter ego or nominee of the taxpayer, to the taxpayer's interest in the underlying assets. Tax noncompliance includes failure to report income from the assets, as well as failure to pay U.S. tax that was due with respect to the funds used to acquire the asset. Id.

98. See id.

99. See Sapirie, supra note 78.

100. See id.

101. See IR-2011-14, supra note 9.

102. See id.

103. See OVDI Deadline Extended Due to Hurricane Irene, supra note 9 (discussing extension). 
greater than the non-fraud statute of limitations periods. ${ }^{104}$ In addition, the general penalty rate in the 2011 program was five percentage points higher than that of the 2009 initiative. The 2011 initiative introduced a $12.5 \%$ penalty and provided for more generous application of the $5 \%$ penalty, but it extended the scope of both reduced penalties to participants in the 2009 initiative, ${ }^{105}$ thereby avoiding disadvantaging taxpayers who made a voluntary disclosure in 2009 rather than waiting until 2011.

In connection with the 2011 program, the IRS provided specific guidance on "opting out" of the penalty structure. "Opting out" involves participating in the initiative but making "an irrevocable election ... to have his or her case handled under the standard audit process." ${ }^{106}$ In other words, under an opt-out, a taxpayer has the penalties determined on an individual basis. While the one-size-fits-all penalties under the 2009 and 2011 programs are lower than what some taxpayers would face, they are higher than the penalties imposed for a non-willful violation of the FBAR requirements. One practitioner explained:

The [voluntary disclosure] penalty applied whether or not the taxpayer knew about the requirement to report the foreign account. ... The programs assume that just because the taxpayer had unreported overseas assets, the taxpayer knew of his legal obligation to report the overseas accounts and to file an FBAR, a form many tax practitioners had not even heard of before 2008.

....

By opting out, a taxpayer takes the chance of a full audit and penalties in excess of what is being offered in the voluntary disclosure program. Although the words "full audit" strike fear in all taxpayers and tax professionals, those are chances worth taking when willfulness clearly does not exist. ${ }^{107}$

104. See I.R.C. § 6501(a) (West 2010) (providing general three-year period); I.R.C. \$ 6501(e) (West 2010) (providing six-year period for substantial omission of items). With respect to the eight-year lookback period in the 2012 initiative, one practitioner stated:

I think many taxpayers who did not act willfully, have strong reasonable cause arguments, and intend to opt out will reject the eight-year lookback period-which covers closed years for many taxpayers-and the required [statute of limitations] extensions, which the IRS cannot force upon a taxpayer outside the settlement initiative.

Marie Sapirie, IRS Announces Open-Ended Third Offshore Voluntary Disclosure Program, Tax Notes Today, Jan. 10, 2012, at 6-1 (quoting tax practitioner Caroline D. Ciraolo).

105. See IRS Updates FAQ on Second Offshore Voluntary Disclosure Initiative, TAX Notes Today, Aug. 25, 2011, at 165-14; see also Sapirie, supra note 75.

106. IRS Explains How to Handle Opt Outs from Civil Settlements Under Offshore Voluntary Disclosure Initiatives, TAx Notes TODAy, June 3, 2011, at 107-39.

107. Jeffrey A. Neiman, Opting Out: The Solution for the Non-Willful OVDI Taxpayer, Tax Notes Today, Sept. 12, 2011, at 176-6. 
Some practitioners praised the 2011 program as addressing concerns raised by the previous initiative. ${ }^{108}$ In 2011 , The IRS reported that almost 12,000 taxpayers filed disclosures under the program. ${ }^{109}$ In early 2012, the IRS reported that it had received 33,000 disclosures under the 2009 and 2011 initiatives. ${ }^{110}$

Perhaps because of the high volume of disclosures in 2009 and 2011, and the fact that "[s]ince the 2011 program closed . . . hundreds of taxpayers have come forward to make voluntary disclosures," 111 the IRS announced an additional offshore voluntary disclosure initiative in 2012. The new initiative is very similar to the 2011 program, except that the highest penalty rate was increased from $25 \%$ to $27.5 \%$, and the program was made indefinite. ${ }^{112}$ Thus, whenever taxpayers choose to come in under the 2012 program, the penalty will apply to "the eight full tax years prior to the disclosure." 113 Therefore, it appears that waiting could remove early tax years from the calculus. The IRS did warn taxpayers, however, that "the terms of the program could change at any time going forward. For example, the IRS may increase penalties in the program for all or some taxpayers or defined classes of taxpayers-or decide to end the program entirely at any point." 114

\section{Are Voluntary Disclosure Initiatives Worthwhile FOR THE GOVERNMENT?}

As discussed above, the IRS's voluntary disclosure initiatives are a form of tax amnesty. ${ }^{115}$ Under all three offshore voluntary disclosure initiatives, the government waived certain penalties, including criminal ones, in return for a disclosure of an undetected tax offense and payment of back taxes for a period of time and some civil penalties. There is thus compromise on both sides: The government collects more than it might otherwise have but less than theoretically it is entitled to, just as it does when it settles a civil tax liability through other means.

108. See Sapirie, supra note 78 ("Practitioners gave the announcement a warm reception. ... The new penalty structure of 25 percent plus amended returns going back to 2003 'hits a good balance,' said Scott D. Michel, a partner at Caplin \& Drysdale.").

109. See Shamik Trivedi, Shulman Touts Success of OVDI, International Tax Enforcement, Tax Notes Today, Sept. 16, 2011, at 180-2.

110. See IR-2012-5, supra note 10.

111. $I d$.

112. See id.

113. Id.

114. $I d$.

115. For a further discussion of how the voluntary disclosure initiatives are a version of a tax amnesty, see supra notes 11-14, and accompanying text. 


\section{A. The Characteristics of an Optimal Tax Amnesty}

As with most compromises, tax amnesties have both benefits and drawbacks. ${ }^{116}$ In an article about offshore tax evasion, Professor Craig Boise identified the benefits of tax amnesties as the collection of tax revenue, encouragement of future tax compliance by taxpayers who participate in the amnesty, and easing a transition to a more stringent enforcement regime. ${ }^{117}$ The first two goals are analogous to the goals of the Offer in Compromise program, under which the IRS may settle known tax liabilities for less than the full amount owed. ${ }^{118}$ The third goal reflects the fact that increased enforcement calls for a change in norms, and amnesties are a form of transition relief. In the offshore context, the U.S. government put a lot more people on notice about their tax obligations ${ }^{119}$ and accomplished major breakthroughs with respect to foreign bank secrecy, but attitudes do not change overnight.

Professor Boise explained in his article that tax amnesties have costs, as well. Those costs include undermining the perceived fairness of the tax system, diminishing the perceived seriousness of the crime of tax evasion, and creating expectations of repeated amnesties that thereby undermine ongoing compliance. ${ }^{120}$ In light of the pros and cons of tax amnesties, Professor Boise developed a very useful list of characteristics for an optimal tax amnesty. Such an amnesty should: (1) be accompanied by reform that will discourage evasion in the future; (2) be accompanied by greater enforcement; (3) be offered only once; (4) minimize perceptions of unfairness by not being offered to known tax evaders and waiving few penalties, ideally only criminal prosecution; and (5) not be relied on principally to raise revenue. ${ }^{121}$

In fleshing out these factors, Professor Boise points out that amnesties accompanied by statutory or administrative reforms bring in more revenue than those not accompanied by such reforms. ${ }^{122}$ They also are more likely to result in improved compliance. ${ }^{123}$ In part, that is because re-

116. See Boise, supra note 12 , at 696-705.

117. See id. at 696-701.

118. The author thanks Keith Fogg for the Offer in Compromise analogy.

119. See IR-2012-5, supra note 10 ("The IRS recognizes that its success in offshore enforcement and in the disclosure programs has raised awareness related to tax filing obligations. This includes awareness by dual citizens and others who may be delinquent in filing, but owe no U.S. tax. The IRS is currently developing procedures by which these taxpayers may come into compliance with U.S. tax law.").

120. See Boise, supra note 12 , at 701-05.

121. See id. at 705-11.

122. See id. at 705 (citing Ines Macho-Stadler et al., Tax Amnesties in a Dynamic Model of Tax Evasion, 1 J. of Pub. Econ. Theory 439, 441 (1999)); William M. Parle \& Mike W. Hirlinger, Evaluating the Use of Tax Amnesty by State Governments, 46 Pub. Admin. Rev. 246, 246 (1986)).

123. See Boise, supra note 12, at 705-06. 
forms may alter the incentives that led to the noncompliance in the first place. ${ }^{124}$

In this regard, an amnesty offered in conjunction with a transition to increased enforcement of the laws subject to the amnesty may be particularly effective at raising revenue. ${ }^{125}$ Publicity about the increased enforcement is also important to increasing compliance. ${ }^{126}$ That increases the perceived likelihood that cheaters will be caught, and increases the incentive to come clean during the amnesty. This also highlights the importance of timing; increased enforcement, such as criminal prosecutions, and publicity about that enforcement, should precede an amnesty, so that taxpayers are aware of a stick as well as a carrot. ${ }^{127}$

Conversely, repeated amnesties are well known to collect less revenue $^{128}$ and to threaten future compliance, as taxpayers perceive unfairness and anticipate further amnesties. ${ }^{129}$ The result may well be diminished compliance as taxpayers avoid being a "chump" complying while others do not, ${ }^{130}$ and anticipate an opportunity to comply later at a reduced cost. ${ }^{131}$

124. See id. at 705 ("After all, if the incentives within the tax system that prompted the tax delinquency remain in place following the amnesty, there is minimal likelihood that tax evaders will change their behavior over the long-term.”).

125. See Leandra Lederman, The Interplay Between Norms and Enforcement in Tax Compliance, 64 Oнго Sт. L.J. 1453, 1465 (2003) (“[E]conomic models of tax compliance counsel that increased audit rates and/or sanctions will increase compliance. ..."); cf. Boise, supra note 12, at 706 (noting that "the failure of Argentina's 1987 amnesty to generate significant revenue was largely attributed to the fact that it was not offered in conjunction with an increase in enforcement activity or any reforms of that country's fiscal system").

126. See Boise, supra note 12, at 706-07 (explaining that "[h] eightened tax enforcement efforts should be highly publicized in order to raise awareness among taxpayers and obtain the maximum signaling benefit," and citing amnesties in California and New York as examples).

127. See Scott D. Michel \& Mark E. Matthews, OVDI Is Over-What's Next for Voluntary Disclosures?, 133 TAx Notes 369, 371 (2011) ("If the IRS wants people to come forward voluntarily, it needs to couple its VDP with well-publicized tax enforcement. . . . With the iron fist hammering away . . . thousands of people will come forward."); $c f$. Boise, supra note 12, at 707 (“[I]n the months leading up to California's 1984-85 amnesty, the State projected a tough and high-profile image on tax enforcement by publicizing criminal tax prosecutions and arrests, publicly seizing boats and luxury cars, and auctioning unusual seized property. . . . The State collected the fifth highest revenue total among states offering tax amnesties." (footnote omitted)).

128. Boise, supra note 12, at 707 ("[E]vidence from both international amnesties and amnesties offered by the states indicates that repeated amnesties generate successively smaller amounts of revenue.").

129. See $i d$. at 708 .

130. See Lederman, supra note 125 , at 1487.

131. See Boise, supra note 12 , at 708 (referencing a study that found that "the average level of compliance generally falls after an amnesty is given, and that this decline is most likely a result of taxpayer expectations of future amnesties, or the 'anticipation effect'" (citing James Alm et al., Amazing Grace: Tax Amnesties and Compliance, 43 NAT'L TAx J. 23, 24 (1990))). 
Similarly, a focus on the fairness of the amnesty to the taxpaying public generally should help to minimize alienation and noncompliance by others. ${ }^{132}$ In addition, although Professor Boise does not focus on this, the design of the amnesty should be such that it is internally fair. That may mean treating differently situated taxpayers differently. One article explains:

One large group of taxpayers in OVDI \#1 comprised persons whose foreign accounts were established by their parents or other family members, with the assets passing by gift or inheritance. Those taxpayers often had knowingly failed to disclose their accounts to their return preparers, and thus they did not report the accounts on FBARs or report the income on their returns. Many of them had family stories involving the Holocaust or political or economic oppression outside the United States. The persons who had opened the accounts originally were often foreign-born and had since died. The funds were rarely earned in the United States, and our clients often relied entirely on nonU.S. financial advisers. ${ }^{133}$

These taxpayers may not warrant the same penalty as taxpayers who opened offshore bank accounts in an effort to evade taxes. ${ }^{134}$

Finally, Professor Boise argues that "an optimal tax amnesty should not be employed principally as a means to raise revenue." 135 In other words, although the net revenue raised by an amnesty is highly relevant, ex post, in evaluating the amnesty's effectiveness, revenue-raising should not be the primary purpose of an amnesty ex ante. Instead, bringing taxpayers into compliance should be.

Although an amnesty typically brings in a large amount of tax dollars in a short time, it may raise less money than expected, particularly if it follows other relatively recent tax amnesties. ${ }^{136}$ In addition, some of what the government collects during an amnesty may have already been identi-

132. See id. at 709.

133. Michel \& Matthews, supra note 127, at 373.

134. See id. ("To us (not to mention to our clients), that group was categorically different than the core tax evader who skimmed funds from a business and deposited them in an overseas account."). The IRS provides a $5 \%$ penalty for some taxpayers in this situation. See id. ("While IRS guidance would have reduced the penalty to 5 percent for some inherited or similar accounts, officials interpreted that guidance so narrowly that we joked about the mythical unicorn. We suspect that out of the thousands of participants in OVDI \#1, very few received that 5 percent safe harbor penalty, even though a large component of the program involved inherited or gifted accounts.").

135. Boise, supra note 12, at 711.

136. See id. at 710 (providing examples by noting that "[a]mnesties in North Dakota, Idaho, Texas, Kansas and Missouri each collected under \$1 million." (citing Alm, supra note 131, at 34)). 
fied by the tax authorities. ${ }^{137}$ Amnesties also typically include a waiver of penalties in order to make the amnesty attractive, and that may represent forgone revenue. ${ }^{138}$ Moreover, it is difficult to determine the longer-term effects of an amnesty, which may include deleterious effects on future compliance. ${ }^{139}$

\section{B. Evaluating the Voluntary Disclosure Initiatives}

Professor Boise's framework provides a helpful context in which to evaluate the IRS's offshore voluntary disclosure initiatives. Each of these initiatives-and the four amnesties as a group-meet most, but not all, of the factors developed by Professor Boise.

First, the voluntary disclosure initiatives were undertaken in conjunction with legislative and administrative reforms designed to target noncompliance generally, and offshore evasion in particular. Some of these efforts focus on increasing transparency of taxpayer information. Congress enhanced the federal whistleblower statute in $2006,{ }^{140}$ and, in connection with its crackdown on offshore tax evasion, enacted FATCA. ${ }^{141}$ The IRS also strengthened its international audit process, such as through the credit card project it began in 2000. ${ }^{142}$ After September 11, 2001, the IRS also entered into tax information exchange agreements (agreements

137. See id. (explaining that "while nearly $30 \%$ of the revenue collected by New York as a result of its 1985-86 amnesty program was from tax liabilities for which the state had no information, the remaining $70 \%$ likely would have been collected anyway" (citing Bonnie G. Ross, Federal Tax Amnesty: Reflecting on the States' Experiences, 40 Tax LaW. 145, 176 (1986))).

138. See id. at 711 ("[W] hatever short-term revenue gains are realized from a tax amnesty also will be reduced to the extent that the amnesty carries with it a waiver of penalties, which is the central attraction of most tax amnesty programs.").

139. See id. (noting that "[a] comprehensive 1995 study that evaluated Indian amnesties offered between 1965 and 1995 found that for all but a single amnesty, the adverse indirect effects overwhelmed the direct amnesty receipts" (citing Arindam Das-Gupta \& Dilip Mookherjee, Tax Amnesties in India: An Empirical Evaluation (Ctr. for Institutional Reform \& the Informal Sector, Working Paper No. 4, 1995))).

140. See I.R.C. $\$ 7623$ (b) (2006); Tax Relief and Healthcare Act of 2006, Pub. L. No. 109-432, $\S 406$ (a), 120 Stat. 2922 (codified as amended at I.R.C. $\S 62$, 7443A, 7623 (2006)) (amending section 7623, among others, of Internal Revenue Code to add awards for whistleblowers); see also Dennis J. Ventry, Jr., Cooperative Tax Regulation, 41 Conn. L. Rev. 431, 459-60 (2008) (explaining 2006 changes under statute, including creation of IRS Whistleblower Office).

141. For a further discussion of FATCA, see supra notes 82-90 and accompanying text. The government also recently enacted a series of new information reporting requirements, in recognition of the fact that information reporting by third parties substantially increases compliance. See Leandra Lederman, Reducing Information Gaps to Reduce the Tax Gap: When Is Information Reporting Warranted?, 78 FordHAm L. REv. 1733, 1736, 1742-52 (2010) (discussing three recently enacted information reporting provisions).

142. For a further discussion of the credit card project, see supra notes 30-35 and accompanying text. 
Villanova Law Review, Vol. 57, Iss. 3 [2012], Art. 5

\begin{tabular}{lllll}
\hline Ijciprod01〉productn\VVLR\57-3\VLR305.txt & unknown & Seq: 24 & 27-NOV-12 & $10: 36$ \\
\hline
\end{tabular}

with a foreign government to exchange tax and other financial information) with countries with which it had not previously had such an agreement. ${ }^{143}$

Second, all of the voluntary disclosure initiatives were accompanied by greater enforcement of the relevant tax laws. In fact, they have generally been in conjunction with special enforcement initiatives, as in the case of the crackdown on Swiss bank accounts. Moreover, those enforcement initiatives have been well publicized-a factor that is helpful in disseminating information about the increased enforcement. ${ }^{144}$

However, the timing of enforcement in relation to the voluntary disclosure programs was not always ideal. Criminal tax prosecutions, in particular, tend to spur increased compliance. ${ }^{145}$ Criminal prosecution and

143. See William M. Sharp, Sr. \& Hale E. Sheppard, Privilege, Work-Product Doctrine, and Other Discovery Defenses in U.S. IRS's International Tax Enforcement, 32 TAx Notes InT'L 377, 394 (2003) (“[I]mmediately following the September 11 tragedies, the IRS has executed a number of TIEAs in its effort to curtail what it considers abusive international tax transactions and also to counter global terrorism. The United States has recently executed TIEAs with the Cayman Islands, the Bahamas, the British Virgin Islands, Antigua and Barbuda, the Netherlands Antilles, Guernsey, the Isle of Man, and Jersey, and several others are under negotiation.").Tax information exchange agreements are a somewhat limited tool, however. See Steven A. Dean, More Cooperation, Less Uniformity: Tax Deharmonization and the Future of the International Tax Regime, 84 Tul. L. REv. 125, 136 (2009) ("Like [double-tax] treaties, TIEAs employ a structure that assigns reciprocal rights and obligations between pairs of states. . . . Although TIEAs are formally reciprocal, because they typically exist between states that are profoundly different, their nominal symmetry tends to be illusory. In practice, one state is likely to need extraterritorial tax information covered by the TIEA while the other does not."); see also Hearing on Banking Secrecy Practices and Wealthy American Taxpayers: Hearing Before the H. Comm. on Ways E् Means, 111th Cong. 69 (2009) (statement of Reuven S. AviYonhan, Irwin I. Cohn Professor of Law, University of Michigan Law School) ("[E]xisting tax information exchange agreements, while helpful and important in some cases, are of limited value in closing the overall international tax gap.").

144. See Boise, supra note 12, at 706-07 (referring to publicity campaigns by New York and California, and the relative success of their amnesties); see also Marie Sapirie, News Analysis: More Written Guidance Needed as OVDI Deadline Nears, TAx Notes Today, Aug. 30, 2011, at 168-1 ("Interest in the OVDI has spiked in recent weeks after a slow initial response from taxpayers with offshore accounts to the announcement of the new program. Practitioners speculate that recent developments such as the announcement of the investigation of Credit Suisse Group in July and the renewed interest of the foreign press in the OVDI are contributing factors to the last-minute rush.").

145. See Internal Revenue Serv., Publ'n 1916 (Rev. 11-96), The DetermiNAnts of Individual Income Tax Compliance: Estimating the Impacts of Tax Policy, Enforcement, And IRS Responsiveness 36 (1996) (copy of Ph.D dissertation proposal of Alan H. Plumley, Harvard University, slightly modified for distribution by Internal Revenue Service) (finding that states with higher number of criminal tax convictions per census population had higher reporting compliance); see also Michel \& Matthews, supra note 127 (“[P] ractitioners have been consulted for decades by clients wishing to initiate voluntary disclosures arising from undeclared offshore accounts or countless other instances of tax noncompliance, but before 2008 those were all largely one-offs. When the enforcement apparatus of the DOJ Tax Division and IRS CI kicked in, taxpayers came into OVDI \#1 in 
conviction of offshore tax evaders-particularly if they are both numerous and publicized-should therefore be an effective way to encourage similarly situated taxpayers to pursue voluntary disclosure. Most of the criminal prosecutions came after the 2003 voluntary disclosure initiative. ${ }^{146}$ Even the 2009 and 2011 initiatives, though much more successful, preceded many indictments, prosecutions, and publicity suggesting that the U.S. government was going after more than UBS bank account holders. ${ }^{147}$ In that regard, the IRS's announcement in early 2012 of an additional, and indefinite, initiative is not surprising.

Of course, these repeated voluntary disclosure regimes violate Professor Boise's criterion that an optimal amnesty should only be offered once. The 2012 program is the third in a series since 2009 of amnesties focusing on offshore bank accounts and other assets. ${ }^{148}$ Moreover, it is actually the fourth offshore voluntary disclosure program since 2003. ${ }^{149}$ It is possible that the 2003 initiative reached a slightly different group of taxpayers from the later initiatives, however. Although the 2003 program was designed to reach "taxpayers who used 'offshore' payment cards or other offshore financial arrangements to hide their income," 150 it was closely connected with the payment card enforcement effort that preceded it. ${ }^{151}$ By contrast, the 2009 and 2011 programs, though of general applicability to offshore noncompliance, ${ }^{152}$ were closely linked with the crackdown on offshore bank accounts. ${ }^{153}$ The 2012 program was announced soon after the close of the 2011 program and is designed in a similar fashion. ${ }^{154}$ Nonetheless, since

droves. With every media report of an indictment against bankers and investment advisers or rumors of investigations into other banks, there was a noticeable uptick in contacts from potential clients.").

146. For a further discussion of increased criminal prosecution after the 2003 initiative, see supra notes 51, 70-75 and accompanying text.

147. For a further discussion of increased enforcement after the 2009 and 2011 initiatives, see supra notes $62-75$ and accompanying text.

148. See IR-2012-5, supra note 10 ("The IRS reopened the Offshore Voluntary Disclosure Program (OVDP) following continued strong interest from taxpayers and tax practitioners after the closure of the 2011 and 2009 programs.").

149. For a further discussion of recent voluntary disclosure programs, see supra notes 1-15 and accompanying text.

150. IR-2003-5, supra note 36, at 1 (emphasis added).

151. For further discussion of the previous payment card information effort, see supra note 39 and accompanying text.

152. See IRS Issues Memorandum, supra note 67 (noting that 2009 program applied to "voluntary disclosure requests containing offshore issues"); IR-2011-14, supra note 9 (2011 initiative was "designed to bring offshore money back into the U.S. tax system and help people with undisclosed income from hidden offshore accounts get current with their taxes.").

153. For further discussion of 2009 and 2011 initiatives, see supra notes 42-51 and accompanying text.

154. See IR-2012-5, supra note 10 (referring to the "continued strong interest from taxpayers and tax practitioners after the closure of the 2011 and 2009 programs" and stating that "[t]he program is similar to the 2011 program in many ways, but with a few key differences" relating to top penalty and lack of specific deadline). 
all four initiatives focused on offshore tax evasion, there is substantial overlap among them.

Professor Boise pointed out that repeated tax amnesties bear the risk of raising considerably less revenue and undermining future compliance. ${ }^{155}$ However, Boise's article does not focus on the specific design of successive amnesties. To its credit, the IRS has raised the general penalty level with each voluntary disclosure initiative, which should help discourage non-compliers inclined to wait for a better "deal." However, in its most recent initiative, the IRS raised the penalty only slightly-from $25 \%$ to $27.5 \%$ - and provided the same eight-year window as the 2011 program. With no deadline to apply, taxpayers with high account or asset values in early years in the eight-year window could wait to apply until those years are out of the window, to receive a lower penalty. Of course, the IRS stated that it could change the terms of the 2012 program or end it at any time, ${ }^{156}$ but the problem is that repeated amnesties undermine the credibility of this threat.

There is also a risk that compliant taxpayers might feel like chumps in the face of a series of highly publicized voluntary disclosure programs. However, criminal prosecutions of taxpayers who come in voluntarily, coupled with the relatively high (and increasing) level of penalties included in the recent initiatives, should help reduce that risk. In addition, the voluntary disclosure initiatives generally were not open to known evaders, but rather only to taxpayers whose evasion was not already known to the IRS. ${ }^{157}$ The "last chance" letters the IRS sent to taxpayers in 2003 after the expiration of the program are an exception because those taxpayers were known to the IRS to be potentially eligible to participate in the offshore initiative. Allowing taxpayers already in the IRS's sights to opt in late to an amnesty program may increase the revenue from that program but it does not send a strong enforcement message. Fortunately, the IRS has not repeated this approach with subsequent amnesties.

With respect to Professor Boise's fourth factor, the voluntary disclosure initiatives do seem intended to raise revenue. However, that is not their only goal. One article explains the two goals of the 2011 initiative as

155. See Boise, supra note 12 , at 707-08.

156. See IR-2012-5, supra note 10.

157. See Rev. Proc. 2003-11, 2003-1 C.B. 311, § 4.01(1) (2003), available at http://www.irs.gov/pub/irs-drop/rp-03-11.pdf (noting that taxpayer's request to participate in 2003 program must have been received before any of four different events occurred, including beginning of IRS audit or criminal investigation of taxpayer); 2011 Offshore Voluntary Disclosure Initiative Frequently Asked Questions and Answers, I.R.S., http://www.irs.gov/businesses/international/article/0, id=235699,00. html (last updated Aug. 29, 2011) ("If the IRS has initiated a civil examination, regardless of whether it relates to undisclosed foreign accounts or undisclosed foreign entities, the taxpayer will not be eligible to come in under the 2011 OVDI.”); see also Parillo \& Coder, supra note 66 ("The reduced penalty scheme will be available only to taxpayers whose disclosure meets the 'voluntary' requirements set out in Internal Revenue Manual 9.5.11.9.”). 
"to (1) incentivize noncompliant, eligible taxpayers to become compliant by setting forth a circumscribed and favorable penalty framework, as evidenced by the much reduced FBAR penalty compared to that of current law and (2) to recoup lost tax revenues." 158 Thus, the revenue-raising goal may not be the government's principal motivation, consistent with Professor Boise's recommendation. In addition, the fact that the IRS increased the penalty level with each initiative seems reflective of a desire not to maximize short-term revenue at the expense of long-term compliance and is thus consistent with a program design that balances factors other than short-term collections.

Ultimately, the success of these amnesties will depend in part on their net collections and on whether they succeed in reducing the amount of offshore evasion in the future, which, in turn, likely depends in large part on the effectiveness and publicity surrounding criminal prosecutions. Unlike the Offer in Compromise program, under which taxpayers agree to be compliant for the next five years, ${ }^{159}$ or risk having the IRS try to collect the full amount that was settled, ${ }^{160}$ the voluntary disclosure regimes do not require any representations about future compliance. ${ }^{161}$ However, the voluntary disclosure programs are designed to allow taxpayers to come into compliance with respect to offshore assets and thereby be able to repatriate the funds in those accounts. To the extent taxpayers do that, they will not be relying on foreign bank secrecy laws to shield those amounts from the IRS in the future.

The longer-term effects the voluntary disclosure initiatives will have on compliance are much harder to measure than their short-term effects. The 2003 initiative may not have raised revenue, net of costs, even in the

158. Alan W. Granwell et al., IRS Issues Voluntary Disclosure Guidance for Unreported Offshore Accounts and Entities, 9 Prac. U.S./Domestic Tax Strategies, Apr. 2009, at 2, 9, available at http://www.dlapiper.com/files/Publication/95e03d3b-70 60-4562-b72d-a46fea0aa4b5/Presentation/PublicationAttachment/5e2a2645-f2364863-8e9e-c85fec262f48/DomTax0409.pdf.

159. See I.R.S. Form 656 (Offer in Compromise) (Mar. 2011) at 3, available at http://www.irs.gov/pub/irs-pdf/f656.pdf (requiring taxpayer to agree to statement, "I will file tax returns and pay required taxes for the five year period beginning with the date of acceptance of this offer, or until my offer is paid in full, whichever is longer. If this is an offer being submitted for joint tax debt, and one of us does not comply with future obligations, only the non-compliant taxpayer will be in default of this agreement.").

160. See id. ("If I fail to meet any of the terms of this offer, the IRS may levy or sue me to collect any amount ranging from the unpaid balance of the offer to the original amount of the tax debt without further notice of any kind. The IRS will continue to add interest, as Section 6601 of the Internal Revenue Code requires, on the amount the IRS determines is due after default. The IRS will add interest from the date I default until I completely satisfy the amount owed.").

161. See Rev. Proc. 2003-11, 2003-1 C.B. 311 (2003 initiative), available at http:/ /www.irs.gov/pub/irs-drop/rp-03-11.pdf; IRS Issues Memorandum, supra note 67 (2009 initiative); IR-2011-14, supra note 9 (2011 initiative). 
short term, ${ }^{162}$ though it seems to have signaled to offshore evaders that the IRS had them in its sights, and laid the groundwork for future offshore enforcement and voluntary disclosure initiatives. The 2009 voluntary disclosure program reportedly raised the much higher amount of $\$ 2.2$ billion, according to the IRS. ${ }^{163}$

It is too soon to tell how much revenue the 2011 disclosure program will raise, though early indications are positive, and the IRS reported in early 2012 that it had collected " $\$ 1$ billion from up front payments required under the 2011 program." 164 Perhaps most important, in conjunction with its overall crackdown on offshore tax evasion, including criminal prosecutions, the 2009 and 2011 voluntary compliance initiatives have provided some cause for optimism:

It's clear that the 2009 offshore voluntary disclosure program (OVDP) and the 2011 OVDI were huge successes. Tens of thousands of Americans participated in the programs. The IRS collected billions of dollars in unpaid taxes, interest, and penalties. Undeclared assets have been reported to the IRS and will be taxed for years to come. The landscape in tax enforcement has forever changed, and the Justice Department and IRS have broken the back of bank secrecy and obtained a treasure-trove of information that will provide fodder for criminal and civil investigations for the next 10 years. ${ }^{165}$

Of course, as with any amnesty, it is hard to determine what effect it will have on taxpayer behavior in the longer term. Some newly compliant taxpayers may stay compliant, reporting earnings on offshore funds, as the IRS hopes. ${ }^{166}$ Other people may invest more resources in evasion, increasing enforcement costs for the IRS. One practitioner, Robert McKenzie,

[F] ound that while the vast majority of potential clients calling him have taken affirmative steps to create their offshore arrangements, the actual numbers of clients retaining him are more evenly split, with 40 percent seeking to disclose inherited accounts. From this, McKenzie concludes that those who have "af-

162. For further discussion of the 2003 initiative, see supra notes $41-42$ and accompanying text.

163. See Trivedi, supra note 109.

164. IR-2012-5, supra note 10.

165. Neiman, supra note 107.

166. See Internal Revenue Serv., Taxpayers Face August 31 Deadline to Come Clean Under Offshore Voluntary Disclosure Initiative, Tax Notes Today, Aug. 9, 2011, at 1536 ("The time has come to get back into compliance with the U.S. tax system, because the risks of hiding money offshore keeps going up,' said IRS Commissioner Doug Shulman. 'Our goal is to get people back into the system.'”); Strategic Priorities, supra note 70 ("Collecting additional revenue for past misdeeds-as important as that may be-is not the main consideration here. It's equally important that we're bringing U.S. taxpayers back into the system . . . back into compliance ... so they properly report and pay their taxes for years to come."). 
firmatively taken steps are not as prone to decide to come into the voluntary disclosure program."167

Another practitioner, Martin Press, termed this group the "risk-takers." 168 "This group is engaged in skimming or otherwise not reporting income received in industries such as international trade. Press said he believed that people in this group are the least likely to come forward under voluntary disclosure."169 These practitioners' experiences suggest that the IRS may be primarily collecting the low-hanging fruit:

"Given the difficulties the IRS has had in obtaining quality information on the accounts in question, including the UBS cases, it suggests to us that even fewer high-income taxpayers will come forward under the harsher [2011] initiative," [Gregory S.] Lynam [of the Ferraro Law Firm] said. "While it is great that the IRS is stepping up use of all of its enforcement tools, there is a danger that the IRS may focus on the little fish that voluntarily swim into the net." 170

Amnesties alone probably will never bring in the risk-takers. To target them, increased global financial transparency and criminal investigations and prosecutions seem to be key. As the government makes strides in those regards, its announcement of the 2012 voluntary disclosure initiative so soon after the end of the last one suggests that it thinks the risk calculus is changing. But it remains to be seen how successful the new program will be, and for what period of time.

\section{Conclusion}

In recent years, the government has marshaled its forces in its battle against offshore tax evasion. Its well-publicized crackdown on the use of secret bank accounts appears to have encouraged a number of taxpayers to participate in the voluntary disclosure initiatives it has offered. The IRS structured the 2011 and 2012 offshore initiatives both to respond to concerns expressed by practitioners and to assure that taxpayers who waited to come in did not face a lower penalty structure than those who made a disclosure under an earlier initiative.

Repeated use of voluntary disclosure initiatives will likely result in diminishing returns, however. The IRS has wisely increased the general penalty each time, rather than offering the same or more attractive terms, which would encourage non-compliers to wait for a better deal, as well as undermining taxpayers' perceptions of the fairness of the federal income tax system generally and the offshore compliance effort in particular. The

167. Stewart, supra note 5.

168. Id.

169. Id.

170. Sapirie, supra note 78. 


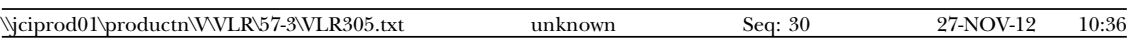

IRS may have concluded that it has reached the limit on penalties for the moment, in that it has no specific deadline under the 2012 program. The lack of a deadline, however, may allow taxpayers to strategically time their disclosure to leave early years outside the eight-year window, where those are years with higher account or asset values.

Moreover, many of the taxpayers who have not already taken advantage of an offshore disclosure initiative may be "risk-takers" engaged in willful evasion who are gambling on continuing to go undetected. In light of this dynamic, the government's best bet is to continue to press forward with obtaining names of U.S. account holders in jurisdictions with strong bank secrecy laws and to prosecute tax evaders criminally when appropriate. 